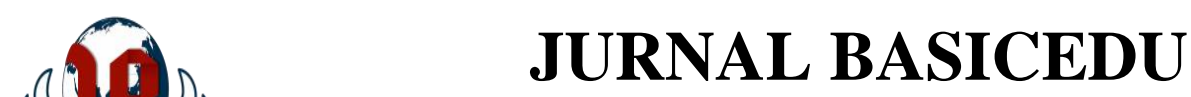

Volume 5 Nomor 3 Tahun 2021 Halaman 1632 - 1638

Research \& Learning in Elementary Education

https://jbasic.org/index.php/basicedu

PAHLAWAN

\title{
Analisis Hambatan Proses Pembelajaran Daring dengan Menggunakan Aplikasi Whatsapp di Sekolah Dasar
}

\author{
Abroto $^{1 凶}$, Andi Prastowo 2 , Raka Anantama ${ }^{3}$ \\ Program Magister PGMI, UIN Sunan Kalijaga Yogyakarta, Indonesia ${ }^{1,2,3}$ \\ E-mail : ahmadabroto05@gmail.com ${ }^{1}, \underline{\text { anditarbiyah@gmail.com }}{ }^{2}, \underline{\text { rakaanatama16@gmail.com }}^{3}$
}

\begin{abstract}
Abstrak
Proses pembelajaran merupakan sebuah interaksi antara guru dan peserta didik dan juga sumber belajar yang dilaksanakan dalam sebuah lingkungan belajar. Penelitian ini bertujuan mengetahui tentang hambatan dalam proses pembelajaran daring dengan menggunakan aplikasi whatsapp. Penelitian ini menggunakan metode kualitatif deskriptif. Teknik pengumpulan data yang digunakan yaitu wawancara, yang subjeknya berupa pendidik dan peserta didik. Analisis data dilakukan dengan reduksi data, display data dan penarikan kesimpulan. Hasil penelitian menunjukkan bahwa guru dan siswa memiliki kendala dalam pelaksanaan pembelajaran daring. Pembelajaran daring efektif untuk mengatasi penularan covid 19, namun pembelajaran daring bukan memudahkan proses pembelajaran namun malah menyulitkan guru dan peserta didik di Sekolah Dasar Negeri No. 79/VII dalam pelaksanaan pembelajaran. Namun, ada kelemahan pembelajaran daring karena kurang nya fasilitas, mulai dari jaringan internet yang jelek, siswa yang belom semua mempunyai whatsapp, dan guru yang kurang menguasai internet sehingga pembelajaran tidak berjalan efektif dan tidak terawasi dengan baik selama proses pembelajaran daring, dan mahalnya biaya kuato menjadi tantangan tersendiri pembelajaran daring.
\end{abstract}

Kata Kunci: Hambatan, Pembelajaran Daring, Aplikasi Whatsapp.

\begin{abstract}
The learning process is an interaction between teachers and students as well as learning resources carried out in a learning environment. This study aims to determine the obstacles in the online learning process using the WhatsApp application. This research uses descriptive qualitative method. The data collection technique used was interviews, the subjects of which were educators and students. Data analysis was performed by reducing data, displaying data and drawing conclusions. The results showed that teachers and students had problems in implementing online learning. Online learning is effective in overcoming covid 19 transmission, but online learning does not facilitate the learning process but instead makes it difficult for teachers and students at Public Elementary School No. 79 / VII in the implementation of learning However, there are weaknesses in online learning due to lack of facilities, starting from a bad internet network, students who don't all have WhatsApp, and teachers who do not master the internet so that learning is not effective and is not well supervised during the learning process online, and the high cost of the quato is a challenge in itself for online learning.
\end{abstract}

Keywords: Barriers, Online Learning, Whatsapp Application

Copyright (c) 2021 Abroto, Andi Prastowo, Raka Anantama

Corresponding author :

Email : ahmadabroto05@gmail.com

DOI $\quad:$ https://doi.org/10.31004/basicedu.v5i3.971

ISSN 2580-3735 (Media Cetak)

ISSN 2580-1147 (Media Online) 
1633 Analisis Hambatan Proses Pembelajaran Daring dengan Menggunakan Aplikasi Whatsapp di Sekolah Dasar - Abroto, Andi Prastowo, Raka Anantama

DOI: https://doi.org/10.31004/basicedu.v5i3.971

\section{PENDAHULUAN}

Keberlangsungan pendidikan di Indonesia terdapat dua faktor penting, yaitu belajar dan pembelajaran. Belajar merupakan sebuah interaksi yang dilakukan antara guru dan siswa secara sadar, baik di dalam atau di luar ruangan yang memiliki tujuan untuk meningkatkan kemampuan siswa (Arindra Evandian Bhagaskara, dkk, 2020: 14). Pembelajaran secara tatap muka di Sekolah Dasar Negeri no. 79/VII di Kasiro Batang Asai resmi diganti dengan pembelajaran dalam jaringan atau daring yaitu sekitar akhir bulan Maret 2020. Sesuai dengan surat edaran kementerian dan kebudayaan, yang menyatakan bahwa proses pembelajaran secara tatap muka tidak boleh dilaksanakan demi menjaga menghambat penularan virus COVID-19. Pembelajaran daring sendiri merupakan pembelajaran yang dilakukan dalam jaringan atau dengan kata lain melalui internet serta alat penunjang lainnya seperti smartphone atau televisi (Sulha, 2020: 23). Akan tetapi proses pembelajarannya sendiri masih tetap bisa berjalan. Karena pembelajaran daring tidak memiliki keterbatasan ruang dan waktu, artinya proses pembelajaran bisa dilaksanakan dimana saja dan kapan saja (Arindra Evandian Bhagaskara, dkk, 2020: 15).

Sedangkan Pembelajaran sendiri jika dilihat dari teori interaksional memiliki makna bahwa proses pembelajaran merupakan sebuah interaksi antara guru dan peserta didik dan juga sumber belajar yang dilaksanakan dalam sebuah lingkungan belajar (Nurdyansyah Nurdyansyah And Eni Fariyatul Fahyuni,2016). Dampak wabah COVID-19 ini sangat dirasakan oleh lapisan penduduk dunia termasuk masyarakat Indonesia. Awalnya dampak ini hanya dirasakan pada aspek ekonomi yang semakin melemah, ternyata dampak wabah COVID-19 ini juga dirasakan oleh semua lapisan aspek kehidupan. Termasuk aspek pendidikan, dalam menghadapi situasi ini Kementerian Pendidikan dan Kebudayaan Republik Indonesia menerbitkan surat edaran nomor 4 tahun 2020 yang mengatur pelaksanaan pendidikan dalam darurat penyebaran COVID-19 (Surat Edaran Mendikbud Nomor 4 Tahun 2020). Anugraha (2020) menjelaskan bahwa beberapa hal yang dapat dilakukan selama pembelajaran daring (daring) adalah saling berkomunikasi dan berdiskusi secara online.

Pembelajaran daring menjadi hal baru di dalam pelaksanaan proses pembelajaran bagi pendidik dan peserta didik. Adanya hambatan pada proses pembelajaran dapat menurunkan minat belajar siswa. Faktorfaktor yang menjadi kunci kesuksesan pembelajaran daring adalah ketersediaan sarana dan prasarana. Pembelajaran daring ini merupakan proses transformasi pendidikan konvensional ke dalam bentuk digital sehingga memiliki tantangan dan peluang tersendiri. Oleh karena itu, hambatan dalam proses pembelajaran daring harus dapat ditemukan solusinya, sehingga sistem pembelajaran daring ke depan dapat dipetakan (Nopiyanto 2020,140). Dampak yang dirasakan oleh pendidik dan peserta didik saat ini adalah mempunyai hambatan dan kesulitan di dalam proses pembelajaran. Hal ini juga berlaku bagi siswa yang ada di pendidikan dasar seperti SD atau MI (Arindra Evandian Bhagaskara, dkk, 2020: 14). Sedangkan pengertian teknologi informasi dan komunikasi, adalah suatu teknologi yang digunakan untuk mengolah data,termasuk memproses, mendapatkan menyimpan, memanipulasi data dalam berbagai cara untuk menghasilkan informasi yang berkualitas (Eni Fariyatul Fahyuni, 2017: 151-152).

Penggunaan teknologi mulai diterapkan dalam pendidikan karena adanya pandangan bahwa diyakini dapat meningkatkan kualitas SDM, berbagai macam produk dan media pembelajaran yang di terapkan dalam pendidikan agar bisa membuat hal baru dalam pendidikan teknologi yang dapat dimanfaatkan dalam pembelajaran. penggunaan TIK dalam pendidikan memilki tiga tahap aspek yaitu: Penggunaan audio visual yaitu alat bantu berbentuk audio (pendengaran) dan visual (penglihatan) di kelas untuk menyampaiakn materi pembelajaran, materi pembelajaran merupakan materi pembelajaran yang di ambil dari subjeck matter, Teknologi meliputi segala hal yang berkaitan dengan proses, penggunaan sebagai alat bantu, dan pengelolaan informasi (Munir, 2009: 140). Teknologi Informasi dan Komunikasi dapat disingkat (TIK) telah berkembang sangat cepat dan telah memberikan hasil yang nyata terhadap peningkatan mutu di ranah pendidikan di 
1634 Analisis Hambatan Proses Pembelajaran Daring dengan Menggunakan Aplikasi Whatsapp di Sekolah Dasar - Abroto, Andi Prastowo, Raka Anantama

DOI: https://doi.org/10.31004/basicedu.v5i3.971

sekolah, khususnya pembelajaran. Pemanfaatan dan pengembangan TIK dalam kegiatan pembelajaran di sekolah. dasar SD/MI agar peserta didik bisa melaksanakan pembelajaran walaupun dalam keadaan daring, maka dibutuhkan sebuah pembaruan di dalam proses pembelajaran, karena kualitas proses pembelajaran sangat berpengaruh terhadap hasil belajar peserta didik. Salah satunya yaitu faktor yang dapat membuat kualitas hasil belajar siswa adalah ketersediaan media pembelajaran.

Perkembangan teknologi dalam dunia pendidikan memiliki sisi positif, namun juga tidak luput dari sisi negatifnya. Maka sering kali terjadi kesalahan dalam mengoperasikan teknologi di dalam penggunaanya, maka disini perlunya seorang tenaga dan sumber daya manusia yang ahli dalam mengelola atau mengoperasikan teknologi dengan tepat sehingga kegunaanya menjadi efektif dan efisien sehngga bisa menjadi sebuah media atau alat untuk meningkatkan mutu pendidikan yang dilakukan (Kukuh Andri Aka, 2017: 30). Pembuatan teknologi untuk pendidikan harus mempertimbangkan nilai-nilai edukasi dan etika dalam menggunakan teknologi maka perlu diterapkan aturan atau batasan di dalam proses pembelajaran yang akan di laksanakan sehingga fungsi dari teknologi pendidikan dapat dimanfaatkan oleh pendidikan semaksimal mungkin (Imroatul Ajizah And Munawir Munawir, 2021: 27).

Di SDN 79/VII kasiro Batang Asai sendiri memiliki kendala atau hambatan dalam melaksanakan pembelajaran secara daring mulai dari aspek tenaga pendidik yang kurang memahami penggunaan internet, sampai kepada peserta didik yang tidak semuanya memiliki handphone oleh karena itu, artikel ini akan membahas tentang kelebihan dan kekurangan di dalam proses pembelajaran daring yaitu melalaui aplikasi whatsapp untuk siswa SDN 79/VII Kasiro Batang Asai Jambi Penggunaan teknologi di dalam proses pelaksanaan pendidikan dalam pembelajaran ini menjadi solusi terakhir yang diambil untuk melanjutkan pelaksanaan pembelajaran, yang berbasis teknologi pendidikan.

Menurut Handarini dalam (Huzaimah and Amelia 2021, 535) bahwa dalam pembelajaran daring membutuhkan sarana dan prasarana yang memadai, seperti laptop,komputer, smartphone, dan jaringan internet. Hal tersebut yang menjadi hambatan yang dialami oleh siswa, karena tidak semua siswa memiliki sarana yang menunjang apalagi di daerah yang mayoritas ekoniminya rendah. Tidak jarang dari mereka yang tidak memiliki penunjang pembelajaran seperti handphone bahkan laptop untuk melakukan pembelajaran secara daring. Penelitian ini dilakukan untuk mengetahui kendala hambatan apa saja yang di alami SDN 79/VII Kasiro Batang Asai Jambi.

\section{METODE PENELITIAN}

Metode penelitian ini menggunakan penelitian dalam pendekatan kualitatif (Suharsimi Arikunto, 2013: 56). Dengan menggunakan metode deskriptif (Wina Sanjaya, 2013: 47). Penelitian ini mendeskripsikan tentang hambatan proses pembelajaran dengan menggunakan aplikasi whatsapp di SDN 79/VII Kasiro Batang Asai Jambi. Subjek dalam penelitian ini adalah wali kelas V dan peserta didik di SDN 79/VII Kasiro Batang Asai Jambi. Teknik pengumpulan data yang digunakan adalah wawancara. Teknik wawancara yang digunakan adalah teknik wawancara tak terstruktur. Tenkik analisis data menggunakan reduksi data, display data dan penarikan kesimpulan.

\section{HASIL DAN PEMBAHASAN}

\section{Hambatan yang dialami Guru/Pendidik}

Di dalam proses pelaksanaan pembelajaran berbasis daring di SDN 79/VII Kasiro Batang Asai Jambi tentu menimbulkan hal baru di dalam pembelajaran yang mana biasaya dilakukan secara formal tatap muka kemudian berubah dengan sistem daring hal ini tentu menjadi tantangan tersendiri bagi Sekolah Dasar 
1635 Analisis Hambatan Proses Pembelajaran Daring dengan Menggunakan Aplikasi Whatsapp di Sekolah Dasar - Abroto, Andi Prastowo, Raka Anantama

DOI: https://doi.org/10.31004/basicedu.v5i3.971

tersebut, mulai dari jaringan internet yang tidak mendukung siswa yang tidak semua memiliki handphone guru yang belom mengusai internet dan hambatan lainya.

Target dalam penelitian ini adalah wali kelas V ibu JM dan beberapa siswa kelas V sekolah dasar Negeri no.79/VII kasiro batang asai. Adapun data dari pertanyaan yang di lanturkan adalah sebagai berikut (Munir, 2009: 140). Hambatan yang di alami oleh guru adalah ada bebebrapa guru yang belom paham dalam menggunakan aplikasi whatsapp dan faktor jaringan internet yang terkadang menjadi permasalahn patal dalam pelaksanaan pembelajaran secara daring. Adapun data jelasnya sebagai berikut:

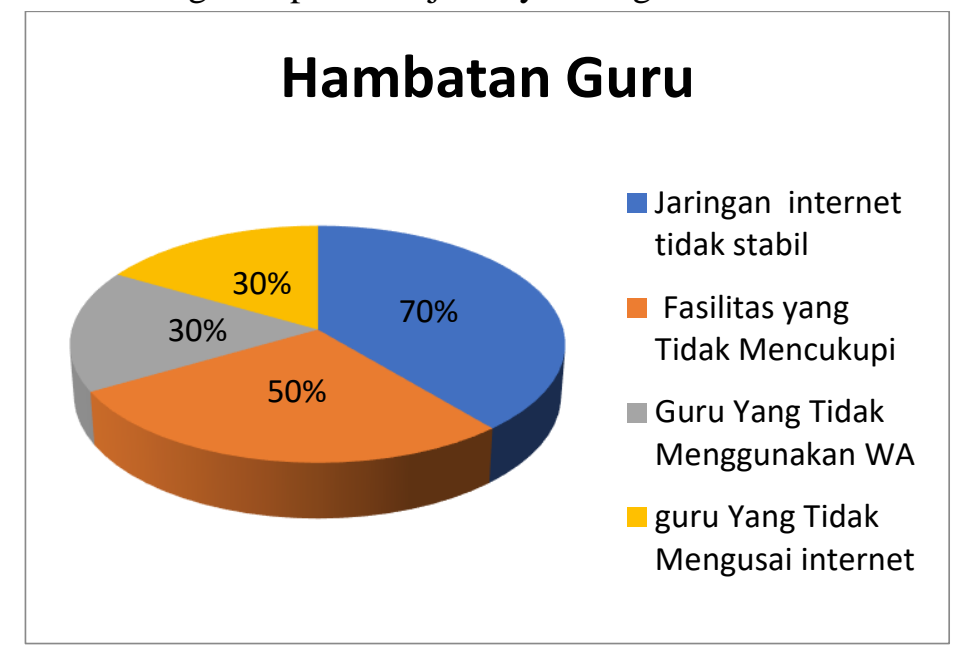

Gambar 1. Data hambatan guru di Sekolah Dasar Negeri No.79/VII kasiro Jambi

Dari gambar di atas dapat di simpulkan bahwa hambatan yang paling besar di alami oleh guru di Sekolah Dasar Negeri No.79/VII adalah tentang kendala jaringan internet sebesar $70 \%$ bearti hampir keseluruhan guru merasakann kendala terhadap jaringan internet yang tidak stabil, kemudian $50 \%$ guru mengalami kurangnya fasilitas yang tidak memadai mulai dari fasilitas sekolah yang kurang memadai sampai ada juga guru yang belum memiliki aplikasi whatsapp. Selanjutnya 30\% guru tidak mempunyai aplikasi whatsapp tentu ini sangat berpengaruh terhadap keberlangsungan pembelajaran daring karena pembelajaran tidak akan efektif tanpa adanya guru untuk mengontrol keberlangsungan di dalam proses pembelajaran apalagi pembeajaran itu berbasis daring. Hambatan terakhir yang di alami guru adalah adanya beberapa guru yang belum menguasai internet yaitu sebesar $30 \%$ guru yang belum tentu ini menjadi hambatan yang patal di dalam pelaksanaan proses pembelajaran berbasis daring. untuk mengatasi kendala yang terjadi ini maka kepala sekolah perlu mengadakan sosialisisi pengenalan terhadap internet agar semua pendidik memahami tentang internet.

\section{Hambatan yang dialami Peserta Didik}

Hal yang sama juga di alami oleh siswa/peserta didik kerana belom terbiasa dengan pembelajaran daring kendala yang di alami oleh guru atau pendidik tentu itu juga di alami oleh peserta didik kelas $\mathrm{V}$ terutama jaringan internet yang tidak stabil di karenakan lokasi sekolah yang berada di pedesaan, masalah selanjutnya yang dialami siswa atau peserta didik yaitu tidak semua peserta didik kelas V memiliki handphone tentu akan menjadi kendala pada saat proses pembelajaran dan kurangnya pengetahuan tentang internet semua itu akan menjadi hambatan di dalam keberlangsungan proses pembelajaran

Proses pembelajaran dengan sistem daring yang dilaksanakan oleh SDN 79/VII Kasiro Batang Asai Jambi khususnya kelas $\mathrm{V}$ dan guru yang mengajar di sekolah tersebut yang menjadi objek penelitian ini tentunya mengalami beberapa permasalah yang telah di sebutkan di atas tadi menjadi hambatan dalam pelaksanaan pembelajaran dan beberapa hambatan yang dialami oleh peserta didik selama proses pembelajaran dengan sistem daring contohnya tadi mulai dari ada beberapa siswa yang tidak memiliki 
handphone, jaringan internet yang kurang bagus, kuota internet yang terbatas, lokasi sekolah yang di pedesaan untuk data lengkapnya akan di jelaskan di bawah ini:

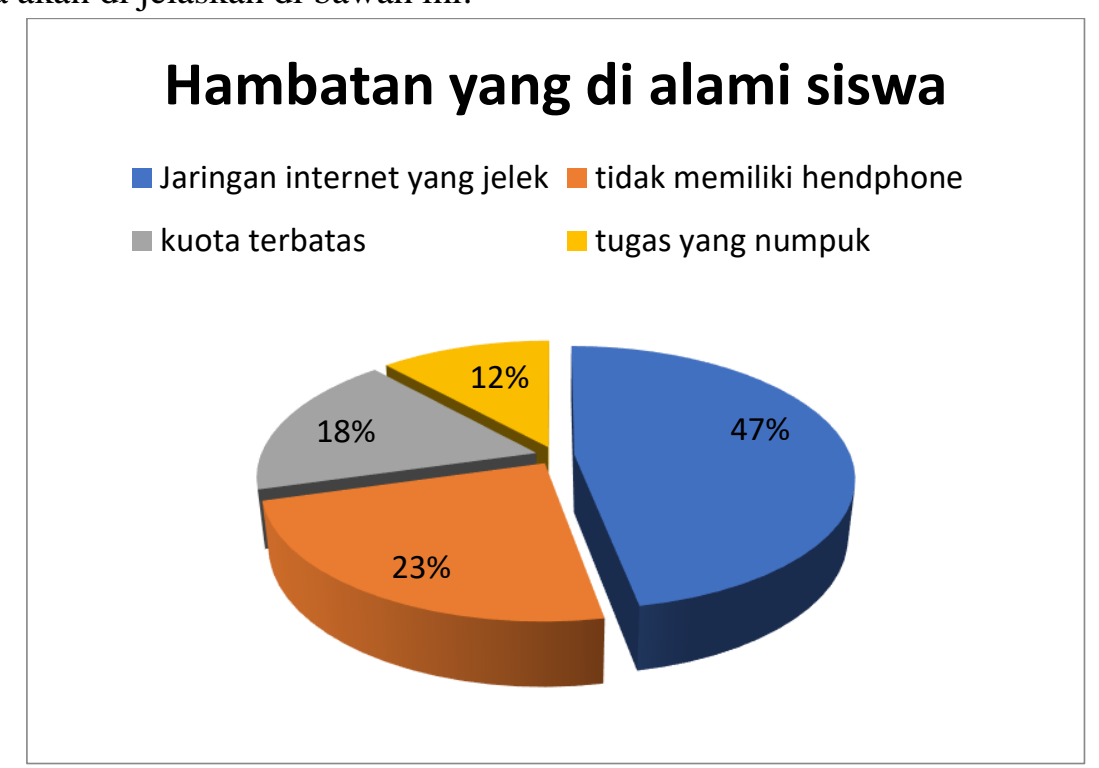

Gambar 2. Hambatan yang di alami oleh Siswa Sekolah Dasar Negeri 79/VII Kasiro Jambi.

Berdasarkan Gambar 2. di atas dapat diketahui beberapa hambatan dalam pembelajaran sistem daring,di Sekolah Dasar Negeri No.79/VII Kasiro Jambi mulai dari jaringan internet yang kurang mendukung 47\%, ada juga beberapa siswa yang tidak memiliki handphone yaitu $23 \%$, tugas yang menumpuk $12 \%$, kuota terbatas $18 \%$, dari data di atas dapat diketahui bahwa kendala yang paling besar di rasakan oleh siswa ayang pertama adalah jaringan internet yang kurang stabil karena lokasi sekolah yang berada di pedesaan ini menjadi kendala yang paling besar di alami oleh peserta didik untuk dilaksanakan pembelajaran daring di Sekolah Dasar Negeri 79/VII Kasiro.

Kendala kedua yang dialami siswa adalah tidak semua siswa mempunyai handphone $23 \%$ jadi siswa/peserta didik yang tidak mempunyai handphone diminta bergabung bersama temanya yang mempunyai handphone siswa juga punya kesulitan dalam proses pembelajaran karena tidak terbiasa menggunakan pembelajaran daring, di tambah lagi dengan jaringan yang tidak stabil karena lokasi di pedesaan, dan pengaruh lainya. Kendala ketiga yang dialami siswa atau peserta didik adalah kuota internet yang terbatas $18 \%$ peserta ddik mengalami ini yang menyebabkan ada sebagian siswa /peserta didik tidak bisa ikut serta pada saat pembelajaran berlansung, dari kendala yang ada tadi mengakibatkan tugas tugas yang diberikan oleh guru menjadi tertumpuk dan menjadi masalah tersendiri bagi siswa.

Keempat faktor tersebut harus diantisipasi oleh semua pihak terutama pihak sekolah dan siswa itu sendiri. Seperti halnya kuota yang terbatas, ini harus diantisifasi oleh pihak sekolah dan orang tua siswa. Pihak sekolah dapat menerapkan beberapa langkah strategis seperti halnya menyiapkan dan menyediakan aplikasi $e$ learning yang rendah kuota (tidak memerlukan kuota internet besar) dalam mengaksesnya. Dan ini dilakukan oleh lembaga lain yang menyediakan aplikasi E-Knows yang tidak memerlukan kuota besar untuk mengaksesnya. Selain itu, terdapat pelayanan berupa kuota gratis puluhan giga bite (GB) dengan cara kerjasama dengan provider untuk mengakses layanan pendidikan (Yuniar Hayati, 2021: 7).

Hambatan terbesar berdasarkan gambar di atas, yang dialami peserta didik adalah jaringan internet yang tidak stabil. Hal ini menjadi hambatan bagi pesert didik, karena kondisi fasilitas untuk pembelajaran dengan sistem daring yang tidak layak dilaksanakan di daerah pedesaan karena fasilitas yang belom tercukupi, kurangnya pengetahuan peserta didik tentang internet akan tetapi, hal ini akan perlahan membaik jika pembelajaran sistem daring ini sudah terbiasa dilaksanakan dalam proses pembelajaran. Selain itu, 
1637 Analisis Hambatan Proses Pembelajaran Daring dengan Menggunakan Aplikasi Whatsapp di Sekolah Dasar - Abroto, Andi Prastowo, Raka Anantama

DOI: https://doi.org/10.31004/basicedu.v5i3.971

komunikasi yang dibangun antara guru dan siswa atau peserta didk penting dilakukan di luar jam pembelajaran untuk mengurangi hambatan tersebut.

Hal ini sesuai dengan penelitian Qurrotaini (2020) yang mengatakan bahwa faktor hambatan yang dirasakan peserta didik dalan pembelajaran IPS SD secara daring antara lain saat peserta didik kurang memahami mengenai materi IPS yang sedang dipelajari, mereka tidak bisa bertanya secara langsung tatap muka dengan guru. Kemudian hambatan lain saat kuota yang habis dan sinyal yang bermasalah jadi tidak bisa mengikuti pembelajaran dengan maksimal. Selain itu orang tua yang masih kesulitan menggunakan teknologi yang ada menjadi hambatan tersendiri dalam pelaksaaan pembelajaran secara daring.

\section{Kekurangan Pembelajaran Menggunakan Aplikasi Whatsapp}

Kebutuhan pendidikan tidak hanya menjadikan peserta didik sebagai passive learner namun juga sebaliknya, pembelajaran berpusat pada peserta didik sehingga peserta bisa mengeksplorasikan berbagai macam ilmu melalui teknologi yang ada saat ini. Peserta didik harus dibekali dengan empat kemampuan pertama: kreatif, komunikatif, berfikit kritis, dan komulatif (Ajizah And Munawir, 2021: 32). Sisi kekurangan dari teknologi juga berdampak pada turunnya kualitas interaksi secara tatap muka di kalangan anak muda. Penelitian yang dilakukan oleh Muclis Aziz dan Nurainiah menunjukkan bahwa penggunaan handphone menyebabkan remaja kurang peka terhadap lingkungan dan menurunkan kualitas pertemuan secara langsung. Padahal teknologi harusnya diciptakan. Untuk membantu pekerjaan masusia sehingga manusia harusnya menguasai teknologi agar teknologi dapat berkembang dan bermanfaat dengan maksimal, bukan malah manusia yang dikuasai oleh teknologi (Ajizah And Munawir, 2021: 43).

Adapun kekurangan pembelajarann berbasis whatsapp vicall /voice note sebagai berikut: (1) Beberapa siswa tidak mempunyai handphone sehingga mempunyai kesulitan di dalam proses pembelajaran, (2) Kecenderungan mengabaikan aspek akademik atau aspek sosial, (3) Ada juga beberapa guru yang tidak paham dalam menggunakan handphone sehingga kesulitan dalam proses pelaksanaan pembelajaran, (4) Berubahnya peran guru dari yang semula menguasai teknik pembelajaran konvensional, kini dituntut untuk menguasai teknik pembelajaran dengan menggunakan ICT (Information Communication Technology), (5) Terkadang jaringan internet menjadi kendala juga di dalam proses pelaksanaan pembelajaran karena sinyal kadang hilang timbul, (6) Peserta didik menjadi kurang aktip di dalam pembelajaran karena sudah terkontaminasi oleh lingkungan sekitar (Suhery, dkk, 2020: 130). Berdasarkan permasalahan diatas solusi atau saran yang dapat dilaksanakaan atau diterapkan oleh pihak sekolah adalah dengan merancang sebuah inovasi pembelajaran atau sistem pembelajaran daring agar pembelajaran dapat tercapai sesuai tujuan yang diharapkan. Misalnya dengan merancang pembelajaran secara luring yaitu dengan membatasi jumlah peserta didik di dalam proses pembelajaran di dalam kelas.

\section{KESIMPULAN}

Dalam rangka memutus mata rantai penyebaran Covid-19 di lingkungan sekolah dasar, maka SDN 79/VII Kasiro Batang Asai melaksanakan pembelajaran daring sebagai solusi pelaksanaan pembelajaran. Hasil penelitian menunjukkan bahwa guru dan siswa memiliki kendala dalam pelaksanaan pembelajaran daring. Pembelajaran daring efektif untuk mengatasi penularan Covid-19, namun pembelajaran daring bukan memudahkan proses pembelajaran namun malah menyulitkan guru dan peserta didik di SDN 79/VII Kasiro Batang Asai dalam pelaksanaan pembelajaran. Namun, ada kelemahan pembelajaran daring karena kurang nya pasilitas, mulai dari jaringan internet yang jelek, siswa yang belom semua mempunyai whatsapp, dan guru yang kurang menguasai internet sehingga pembelajaran tidak berjalan efektif dan tidak terawasi dengan baik selama proses pembelajaran daring, dan mahalnya biaya kuota menjadi tantangan tersendiri pembelajaran daring. 
1638 Analisis Hambatan Proses Pembelajaran Daring dengan Menggunakan Aplikasi Whatsapp di Sekolah Dasar - Abroto, Andi Prastowo, Raka Anantama

DOI: https://doi.org/10.31004/basicedu.v5i3.971

\section{DAFTAR PUSTAKA}

Ajizah, Imroatul, and Munawir Munawir. 2021. "Urgensi Teknologi Pendidikan: Analisis Kelebihan Dan Kekurangan Teknologi Pendidikan Di Era Revolusi Industri 4.0." ISTIGHNA: Jurnal Pendidikan Dan Pemikiran Islam 4 (1): 25-36.

Aka, Kukuh Andri. 2017. "Pemanfaatan Teknologi Informasi dan Komunikasi (TIK) Sebagai Wujud Inovasi Sumber Belajar di Sekolah Dasar." ELSE (Elementary School Education Journal) : Jurnal Pendidikan dan Pembelajaran Sekolah Dasar 1 (2a).

Anugrahana, Andri. 2020. "Hambatan, Solusi Dan Harapan: Pembelajaran Daring Selama Masa Pandemi Covid-19 Oleh Guru Sekolah Dasar." Scholaria: Jurnal Pendidikan Dan Kebudayaan 10 (3): 282-89.

Arikunto, Suharsimi. 2013. Prosedur Penelitian Suatu Pendekatan Praktis. Jakarta: Rineka Cipta.

Bhagaskara, Arindra Evandian, Eka Nur Afifah, and Enggar Maulana Putra. n.d. "Pembelajaran Dalam Jaringan (Daring) Berbasis Whatsapp Di Sd Yapita," 11.

Fahyuni, Eni Fariyatul. 2017. Kurikulum,Berbasis, Teknologi, Informasi, Dan Komunikasi. Sidoarjo: UMSIDA Press.

Hayati, Yuniar. 2021. "Pembelajaran Daring Bervariasi Di Masa Covid-19 Untuk Meningkatkan Keaktifan Peserta Didik Smpn 4 Mataram." TEACHING : Jurnal Inovasi Keguruan Dan Ilmu Pendidikan 1 (1): $36-42$.

Huzaimah, Pipip Zulfa, and Risma Amelia. 2021. "Hambatan Yang Dialami Siswa Dalam Pembelajaran Daring Matematika Pada Masa Pandemi COVID-19.” Jurnal Cendekia : Jurnal Pendidikan Matematika 5 (1): 533-41.

Munir. 2009. Kurikulum, Berbasis, Teknologi,Informasi, Dan Komunikasi. Bandung: Alfabeta.

Nopiyanto, Yahya Eko. 2020. "Hambatan Guru Pendidikan Jasmani Generasi 80-an Dalam Pembelajaran Daring Di Tengah Pandemi Covid-19.” Jurnal Sporta Saintika 5 (2): 139-48.

Nurdyansyah, Nurdyansyah, and Eni Fariyatul Fahyuni. 2016. Inovasi Model Pembelajaran Sesuai Kurikulum 2013. Nizamia Learning Center.

Qurrotaini, Lativa, Nabilah Khusnussyifa, Venni Herli Sundi, and Laily Nurmalia. 2020. "Analisis Faktor Hambatan Penerapan IPS SD pada Pembelajaran Daring." Prosiding Seminar Nasional Penelitian LPPM UMJ 1 (1).

Sanjaya, Wina. 2013. Penelitian Pendidikan Jenis, Metode Dan Prosedur. Jakarta: Kencana.

Suhery, Suhery, Trimardi Jaya Putra, and Jasmalinda Jasmalinda. 2020. "Sosialisasi Penggunaan Aplikasi Zoom Meeting Dan Google Classroom Pada Guru Di Sdn 17 Mata Air Padang Selatan.” Jurnal Inovasi Penelitian 1 (3): 129-32.

Sulha, Sulha. 2020. "Penerapan Montessori Dalam Pembelajaran Matematika Melalui Luring Sebagai Alternatif Masa Pandemi.” Prismatika: Jurnal Pendidikan Dan Riset Matematika 3 (1): 22-30.

Surat Edaran Mendikbud Nomor 4 Tahun 2020.” 2020. GTKDIKMENDIKSUS 2020 (blog). May 8, 2020. 